\title{
Current disease modifying approaches to treat Parkinson's disease
}

\section{Lindholm, Dan}

2016-04

Lindholm , D , Mäkelä , J , Di Liberto , V , Mudo , G, Belluardo , N , Eriksson-Rosenberg , O \& Saarma , M 2016 , ' Current disease modifying approaches to treat Parkinson's disease ', Cellular and Molecular Life Sciences , vol. 73 , no. 7 , pp. 1365-1379 . https://doi.org/10.1007/s00018-015-2101-1

http://hdl.handle.net/10138/223922

https://doi.org/10.1007/s00018-015-2101-1

publishedVersion

Downloaded from Helda, University of Helsinki institutional repository.

This is an electronic reprint of the original article.

This reprint may differ from the original in pagination and typographic detail.

Please cite the original version. 


\title{
Current disease modifying approaches to treat Parkinson's disease
}

\author{
Dan Lindholm ${ }^{1,2} \cdot$ Johanna Mäkelä ${ }^{1,2} \cdot$ Valentina Di Liberto $^{3} \cdot$ Giuseppa Mudò $^{3}$. \\ Natale Belluardo $^{3} \cdot$ Ove Eriksson $^{1} \cdot$ Mart Saarma $^{4}$
}

Received: 5 October 2015/Revised: 18 November 2015/Accepted: 23 November 2015/Published online: 30 November 2015

(c) Springer International Publishing 2015

\begin{abstract}
Parkinson's disease (PD is a progressive neurological disorder characterized by the degeneration and death of midbrain dopamine and non-dopamine neurons in the brain leading to motor dysfunctions and other symptoms, which seriously influence the quality of life of PD patients. The drug L-dopa can alleviate the motor symptoms in PD, but so far there are no rational therapies targeting the underlying neurodegenerative processes. Despite intensive research, the molecular mechanisms causing neuronal loss are not fully understood which has hampered the development of new drugs and diseasemodifying therapies. Neurotrophic factors are by virtue of their survival promoting activities attract candidates to counteract and possibly halt cell degeneration in PD. In particular, studies employing glial cell line-derived neurotrophic factor (GDNF) and its family member neurturin (NRTN), as well as the recently described cerebral dopamine neurotrophic factor (CDNF) and the mesencephalic astrocyte-derived neurotrophic factor (MANF) have shown positive results in protecting and repairing dopaminergic neurons in various models of PD. Other substances with
\end{abstract}

Dan Lindholm

dan.lindholm@helsinki.fi

1 Medicum, Department of Biochemistry and Developmental Biology, Medical Faculty, University of Helsinki, P.O.Box 63, 00014 Helsinki, Finland

2 Minerva Medical Research Institute, Biomedicum-2 Helsinki, Tukholmankatu 8, 00290 Helsinki, Finland

3 Division of Human Physiology, Department of Experimental Biomedicine and Clinical Neuroscience, University of Palermo, Corso Tukory 129, 90134 Palermo, Italy

4 Institute of Biotechnology, University of Helsinki, P.O.Box 56, Viikinkaari 9, 00014 Helsinki, Finland trophic actions in dopaminergic neurons include neuropeptides and small compounds that target different pathways impaired in PD, such as increased cell stress, protein handling defects, dysfunctional mitochondria and neuroinflammation. In this review, we will highlight the recent developments in this field with a focus on trophic factors and substances having the potential to beneficially influence the viability and functions of dopaminergic neurons as shown in preclinical or in animal models of PD.

Keywords Neurotrophic factors - Neuropeptides · Dopamine neurons $\cdot \alpha$-Synuclein $\cdot$ ER stress .

Mitochondria $\cdot$ Protein aggregation $\cdot$ Neuroinflammation

\section{Introduction}

Parkinson's disease (PD) is after Alzheimer's disease the second most common neurodegenerative disorder and affects about $1 \%$ of the elderly population. Currently there are 7-8 million patients with PD. A known risk factor for $\mathrm{PD}$ is age suggesting that the prevalence of PD is likely to increase among the aging population worldwide. The debut of the disease is usually around the age of 60 with a progress of symptoms over time. Like other human diseases PD has a subclinical phase and a clinical phase with overt symptoms that bring the patient to the doctor. The clinical manifestation of PD is associated with severe motor symptoms such as resting tremor, rigidity, hypokinesia and gait dysfunctions. This is associated with the decline in dopamine levels, and with the degeneration and loss of dopaminergic neurons in the substantia nigra pars compacta (SNpc) leading to alterations in nigrostrial neuronal circuitries. However, patients afflicted with PD have also various non-motor symptoms such as impairment of smell, 
autonomic dysfunctions, depression, lack of motivation, sleep disorders and later on reduced cognitive abilities and dementia. The ultimate goal of a sustainable diseasemodifying treatment in PD is to slow down or even stop disease progression by addressing the degenerative process in all different types of neurons. Ideally, in disease-modifying therapies degenerating neurons can be regenerated and the functional activity of the remaining neurons gets enhanced. It is important to emphasise that neuroprotective strategies should be directed to the presymptomatic phase of the disease so as to restrain the continuous loss of viable neurons in PD. For this, the development of novel biomarkers and diagnostics are urgent and prerequisites for a better treatment of PD in the future.

Basic research into the genetics and pathophysiology of PD has increased our understanding about the fundamental processes causing neurodegeneration and cell dysfunctions and helped to identify novel and promising targets for neuroprotection. Here, we will discuss possible neuroprotective strategies to target cellular events occurring in PD such as increased endoplasmic reticulum (ER) stress, mitochondria dysfunctions, protein aggregation as well as neuroinflammation. We also review recent developments in the use of neurotrophic factors and disease-modifying drugs with potentials to slow the disease process and to provide recovery of neuronal functions in PD.

\section{Genetics and pathogenetic mechanisms in PD}

Despite intense research on pathogenetic mechanisms, we still do know little about the primary insult(s) that trigger changes in vulnerable neurons in PD at the initial stage of the disease. However, there is increasing number of genes that have been identified that predispose to motor symptoms and PD. Studies of the genetics of PD have revealed alterations in specific genes and proteins that are linked to the disease $[1,2]$. These include mutations in the genes for $\alpha$-synuclein $(\alpha$-syn) also called PARK1, Parkin/PARK2, PINK-1/PARK6, DJ-1/PARK7, LRRK2/PARK8 and others (see Table 1). It is interesting to note that mutations in the $\alpha$-syn were the first that clearly linked genes to PD. The functions of these gene products are associated with specific intracellular pathways and cell organelle systems that contribute to the pathophysiology of PD (Table 1). Around 5-10 \% of all PD cases are familial forms, whereas the majority of patients have a sporadic form of PD with no obvious or so far identified genetic cause.

Pathogenetic mechanisms in PD include mitochondrial dysfunctions, calcium dysregulation, altered cell signaling, increased oxidative and ER stress, as well as a disturbed protein handling (proteostasis) with the accumulation and aggregation of unfolded or mutant proteins accompanied by defects in autophagy or in the ubiquitin-proteasome system (UPS) [3-5]. Moreover, an increased neuroinflammation and a reduced trophic support in the brain are also thought to contribute to PD. The selective vulnerability of dopamine neurons in SNpc in PD was recently related to an intrinsic pacemaker activity driven by a specific subtype of L-type voltage-dependent $\mathrm{Ca}^{2+}$ channels expressed by these neurons [6]. The dopaminergic neurons are thought to have a high-energy demand reflected by an enhanced rate of oxidative phosphorylation and with increased production of reactive oxidative species (ROS) causing oxidative stress [7]. A better understanding of the disease-causing processes in PD is a prerequisite for the development of neuroprotective treatments and novel disease-modifying agents in PD.

\section{Protein aggregation and misfolding in PD}

PD is characterized by the presence of intraneuronal inclusions identified in post-mortem tissue and named Lewy bodies in cell soma and Lewy neurites in neuronal processes (reviewed in 8). The protein aggregates contain misfolded $\alpha$-syn which is a presynaptic protein with a physiologic role linked to regulation of vesicle turnover and neurotransmission $[8,9] . \boldsymbol{\alpha}$-syn is normally present as monomer in cells but mutant or misfolded $\alpha$-syn accumulates as oligomers or filaments in different neuronal compartments, in axons, in the cell soma and in dendrites $[8,9]$. Large-scale proteomic studies have shown that monomeric and oligomeric $\alpha$-syn can interact with a specific set of cellular proteins [10]. $\alpha$-syn is also known to interact with intracellular membranes and organelles which may help to explain its multiple actions in pathophysiological processes leading to PD (see below). The significance of $\alpha$-syn in pathogenesis of PD is revealed by mutations in $\alpha$-syn and by $\alpha$-syn gene duplication or triplication which were also shown to cause PD [1,2].

$\alpha$-syn is usually degraded by autophagy-lysosome system including chaperon-mediated autophagy [11] and disturbances in autophagy-lysosomal system can contribute to its toxicity and accumulation in the cell and triggering ER stress $[12,13]$. A recent development regarding PD is the finding that about $5-10 \%$ of PD patients, depending on the population backgroundis estimated to carry mutations in the lysosomal enzyme, glucocerebrosidase (GBA) making it a major risk factor for PD [14]. Homozygous GBA mutations cause Gaucher disease (GD) a lysosomal storage disorder with accumulation of the sphingolipid, glucosylceramide that affects different organs [14]. A major neurologic complication in GD is Parkinsonism with clinical signs and Lewy body inclusions largely indistinguishable from sporadic PD. Heterozygote GD patients 
Table 1 Genes associated with familial forms of PD

\begin{tabular}{|c|c|c|c|c|}
\hline Locus & Gene & Inheritance & Disorder & Function \\
\hline $\begin{array}{l}\text { PARK1, } \\
\text { PARK4 }\end{array}$ & SNCA & $\begin{array}{l}\text { Autosomal dominant; } \\
\text { sporadic }\end{array}$ & Early onset PD & Involved in synaptic vesicle formation \\
\hline PARK2 & Parkin & $\begin{array}{l}\text { Autosomal recessive; } \\
\text { sporadic }\end{array}$ & Juvenile and early onset PD & E3 ligase \\
\hline PARK6 & PINK1 & Autosomal recessive & Early onset PD & Mitochondrial kinase \\
\hline PARK7 & DJ-1 & Autosomal recessive & Early onset PD & Involved in oxidative stress response \\
\hline PARK8 & LRRK2 & $\begin{array}{l}\text { Autosomal dominant; } \\
\text { sporadic }\end{array}$ & Late onset PD & Protein kinase \\
\hline PARK9 & ATP13A2 & Autosomal recessive & Kufor-Rakeb syndrome & P-type transport ATPase \\
\hline \multicolumn{5}{|c|}{ Putative locus/gene } \\
\hline PARK 3 & Unknown & Autosomal dominant & Late onset PD & Unknown \\
\hline PARK5 & UCHL1 & Autosomal dominant & Late onset PD & Ubiquitin-protein hydrolase \\
\hline PARK10 & Unknown & Unclear & Late onset PD & Unknown \\
\hline PARK11 & GIGYF2 & Autosomal dominant & Late onset PD & $\begin{array}{l}\text { Involved in cellular insulin and insulin-like growth } \\
\text { factor response }\end{array}$ \\
\hline PARK12 & Unknown & Risk factor & Late onset PD & Unknown \\
\hline PARK13 & $\begin{array}{l}\text { Omi/ } \\
\text { HTRA2 }\end{array}$ & $\begin{array}{l}\text { Autosomal dominant or risk } \\
\text { factor }\end{array}$ & Late onset PD & Mitochondrial-targeted serine protease \\
\hline PARK14 & PLA2G6 & Autosomal recessive & $\begin{array}{l}\text { Early onset dystonia- } \\
\text { parkinsonism }\end{array}$ & A2 phospholipase \\
\hline PARK15 & FBXO7 & Autosomal recessive & Early onset parkinsonian & E3 ubiquitin protein ligase complex \\
\hline PARK16 & Unknown & Risk factor & Late onset PD & Unknown \\
\hline PARK17 & VPS35 & Autosomal dominant & Late onset PD & Component of the retrograde cargo-selective complex \\
\hline \multirow[t]{3}{*}{ PARK18 } & EIF4G1 & Autosomal dominant & Late onset PD & Component of eIF4F complex at the ribosome \\
\hline & GBA & Risk factor & Early onset PD & Lysosomal enzyme \\
\hline & DAT & Risk factor & Early onset PD & Dopamine uptake \\
\hline
\end{tabular}

Modified from $[1,2]$. SNCA $\alpha$-synuclein, PINK1 PTEN induced putative kinase $1, D J-1$ protein deglycase DJ-1, LRRK2 leucine rich repeat kinase 2, ATP13A2 ATPase type 13A2, UCHL1 ubiquitin carboxyl-terminal esterase L1, GIGYF2 GBR10 interacting GYF protein 2, Omi/ HTRA2 serine protease HTRA2, mitochondrial, PLA2G6 phospholipase A2, group VI, FBXO7 F-Box protein 7, VPS35 vacuolar protein sortingassociated protein 35, EIF4G1 eukaryotic translation initiation factor 4 gamma1, GBA beta-glucocerebrosidase, DAT dopamine transporter

have an increased frequency of developing PD, and biochemical analyses showed reduced GBA enzyme activity in substantia nigra in PD patients with $G B A$ mutations as well as in sporadic PD [14, 15]. Recent data suggest that accumulation of lipid substrates does not occur in brains of PD patients with mutant GBA, suggesting other mechanisms for neurodegeneration [16]. Studies have shown that mutant GBA can accumulate in the ER and thereby may cause ER stress [14]. There is further a functional relationship between GBA and $\alpha$-syn levels in the cell [17] that may provide novel targets for neuroprotection.

To understand the sequel and neuropathology of sporadic $\mathrm{PD}$, Braak and colleagues characterized up to six stages of the disease based upon immunoreactive $\alpha$-syn neuronal inclusions in autopsy material from PD patients [18]. $\alpha$-syn inclusions were initially observed in regions such as the olfactory bulb and the dorsal motor nucleus of the vagus nerve in the brain stem, thereafter spreading to other neurons in the brain stem, amygdala, cortex and striatum $[18,19]$. Moreover, $\boldsymbol{\alpha}$-syn aggregates have been detected in enteric neurons even before the diagnosis of motor symptoms in PD patients. At later stages Lewy pathology was widespread with worsening of clinical symptoms in patients and with the decline in dopamine concentration in the brain. Axonal transport is likely involved in the spreading and transfer of a $\alpha$-syn in the brain as it follows specific anatomic tracts $[9,20]$. There is also some evidence that $\alpha$-syn can propagate from cell to cell via the extracellular space, and misfolded $\alpha$-syn may act as a seed for protein aggregation via a prion-like mechanism $[9,20]$.

The vagal nerve has a widespread innervation to several targets including internal organs in the body. Recent studies have provided some evidence that the gut microbiome is altered in PD and related to motor phenotype [21]. It is so far unclear, what pathophysiological roles these changes may play in the disease and whether such changes could serve as biomarkers in PD.

Hindrance of $\alpha$-syn spreading by blocking of extraneuronal $\alpha$-syn by specific compounds or using immunization 
Table 2 Examples of clinical trials using disease-modifying agents in Parkinsons disease

\begin{tabular}{|c|c|c|c|c|}
\hline Conditions & Aim of the study & Disease group & $\begin{array}{l}\text { ClinicalTrials.gov } \\
\text { identifier }\end{array}$ & Comments \\
\hline $\begin{array}{l}\text { AAV2-GDNF bilateral } \\
\text { intraputamental infusions }\end{array}$ & $\begin{array}{l}\text { Safety trial using } 4 \\
\text { different doses of } \\
\text { AAV2-GDNF }\end{array}$ & Advanced PD & NCT01621581 & Phase I recruiting \\
\hline $\begin{array}{l}\text { Recombinant GDNF } \\
\text { (9-11 } \mathrm{mg} / \mathrm{ml}) \text { intermittent } \\
\text { bilateral intraputamen } \\
\text { infusions }\end{array}$ & $\begin{array}{l}\text { Effect on OFF-state } \\
\text { motor function at } \\
9 \text { months }\end{array}$ & PD & $\begin{array}{l}\text { EUCTR2011- } \\
\text { 003866-34-GB }\end{array}$ & Phase II ongoing \\
\hline $\begin{array}{l}\text { Recombinant GDNF } \\
(9-11 \mathrm{mg} / \mathrm{ml}) \text { intermittent } \\
\text { bilateral intraputamen } \\
\text { infusions }\end{array}$ & $\begin{array}{l}\text { As above comparing } \\
\text { effects at } 18 \text { and } \\
9 \text { months of } \\
\text { treatment }\end{array}$ & PD & $\begin{array}{l}\text { EUCTR2013- } \\
\text { 001881-40-GB }\end{array}$ & Phase II ongoing \\
\hline $\begin{array}{l}\text { Recombinant PDGF-BB into } \\
\text { brain ventricle using } \\
\text { catheter }\end{array}$ & $\begin{array}{l}\text { Safety trial: infusion } \\
\text { into brain for } \\
2 \text { weeks }\end{array}$ & Moderate PD & NCT00866502 & $\begin{array}{l}\text { Phase } 1 \text { completed: Safe and well tolerated more } \\
\text { studies planned }\end{array}$ \\
\hline $\begin{array}{l}\text { Pioglitazone daily } 15 \text { or } \\
\quad 40 \mathrm{mg}\end{array}$ & $\begin{array}{l}\text { Effect on progression } \\
\text { of PD }\end{array}$ & $\begin{array}{l}210 \text { patients } \\
\text { with early } \\
\text { PD }\end{array}$ & NCT01280123 & $\begin{array}{l}\text { Phase } 2 \text { completed: showed no significant clinical } \\
\text { benefit }\end{array}$ \\
\hline $\begin{array}{l}\text { Exenatide daily injections } \\
\text { for } 12 \text { months }\end{array}$ & $\begin{array}{l}\text { Effect on motor and } \\
\text { cognitive functions }\end{array}$ & $\begin{array}{l}\text { Moderate PD } \\
45 \text { patients } \\
\text { no placebo } \\
\text { group }\end{array}$ & NCT01174810 & $\begin{array}{l}\text { Phase } 2 \text { completed: clinical improvements at } \\
12 \text { months with persistent effects after } 12 \text { months } \\
\text { of drug withdrawal studies planned using slow- } \\
\text { release form of drug }\end{array}$ \\
\hline $\begin{array}{l}\text { Immunotherapy using } \\
\text { monoclonal anti- } \alpha \text {-syn } \\
\text { antibodies (PRX002) }\end{array}$ & $\begin{array}{l}\text { Safety trial effect on } \\
\alpha \text {-syn levels }\end{array}$ & $\begin{array}{l}\text { Normal healthy } \\
\text { subject then } \\
\text { PD patients }\end{array}$ & $\begin{array}{l}\text { NCT02095171 } \\
\text { NCT02157714 }\end{array}$ & $\begin{array}{l}\text { Phase } 1 \text { completed: no adverse effects shown, } \alpha \text {-syn } \\
\text { reduced in serum. Now PD patients are recruited }\end{array}$ \\
\hline
\end{tabular}

strategies are promising approaches to reduce the burden of $\alpha$-syn in the brain to possibly halt the progression of PD [20, 22]. Preclinical studies along these research lines have shown promising results [22, 23], and currently various immunotherapies based upon active (injection of recombinant $\alpha$-syn) and passive immunization (injection of domain-specific anti- $\alpha$-syn antibodies) procedures are in clinical testing or are being planned for PD patients (Table 2). As reviewed recently the processing, oligomerization and aggregation of intracellular $\alpha$-syn are also potential targets for the development of disease-modifying therapies in PD showing encouraging results [20, 22].

\section{ER stress in PD}

The unfolded protein response (UPR) is a conserved cellular process in the endoplasmic reticulum by which the cells respond to oxidative stress, increased calcium levels and a disturbed protein homeostasis with the accumulation of misfolded, aggregated or mutant proteins in the ER that are normally processed by the proteasome or autophagy systems [24]. The UPR is usually protective and engages specific signaling pathways and chaperones to restore cell homeostasis and protein refolding (Fig. 1). However, prolonged and sustained UPR activation can lead to full blow ER stress with the activation of pathways linked to cell degeneration and finally triggering cell death [24]. Experimental evidence suggests that UPR regulates the ER stress of the cell by three different pathways: mRNA degradation and suppression of further protein synthesis, enhancement of protein refolding by the induction of ER chaperons and activation of ER-associated degradation of unfolded proteins. Three ER transmembrane receptors mediate UPR: inositol-requiring enzyme 1 (IRE1), pancreatic ER kinaselike ER kinase (PERK) and activating transcription factor 6 (ATF6). These transmembrane receptors are activated in ER stress by dissociating from an ER chaperone GRP78 (alias BiP) that is associated with several proteins (Fig. 1). Phosphorylated PERK blocks general mRNA translation by phosphorylating eukaryotic initiation factor $2 \alpha$ (eIF2 $\alpha$ ). However, transcription factor ATF4 is produced despite translation initiation block. ATF6 and IRE1 pathways regulate the expression of ER chaperone genes and IRE1 degrades mRNA and, through spliced X-box binding protein (XBP1), induces the expression of genes for protein degradation. At later stages $\mathrm{C} / \mathrm{EBP}$-homologous protein (CHOP) can trigger the apoptotic response.

ER stress is thought to play an important role in the pathogenesis of neurodegenerative diseases including PD $[25,26]$. Thus the neurotoxins, 6-hydroxydopamine (6OHDA) and $N$-methyl-4-phenyl-1, 2,3,6-tetrahydroyridine (MPTP) produce oxidative damage with an increased production of ROS and ER stress in cultured dopaminergic 


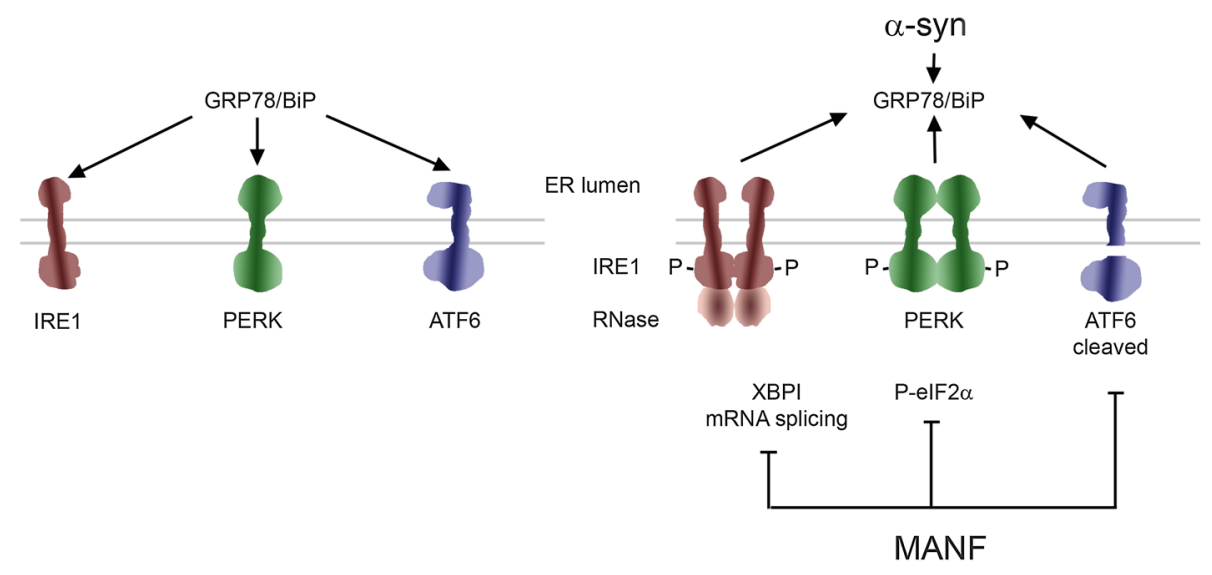

Fig. 1 Unfolded protein response and ER stress signaling pathways in PD. The unfolded protein response (UPR) is a conserved pathway for regulating protein homeostasis in the cell and it is controlled by the chaperon GRP78/BIP protein complex in the ER (left). There are three signaling pathways (IRE1, PERK and ATF6 for detail see text) for UPR that become activated under conditions of cell stress, following dysregulation of cell calcium and accumulation of misfolded or mutant disease-causing proteins such as $\alpha$-synuclein

neurons [27]. Recently, it was shown that UPR markers are present in post-mortem brain of patients with Lewy body disease including PD [28]. Furthermore, neurons derived form induced pluripotent stem cells of PD patients showed defects in protein handling which was linked to an activated ER stress response [29]. Development of neuroprotective substances targeting signaling cascades linked to ER stress could therefore be of value also in PD. However, the situation is complex since the three ER signaling cascades serve different functions in the context of cell viability and a mild cell stress involving the UPR is likely to be protective [30]. Studies of mice with gene deleted of different ER stress signaling components showed that dopaminergic neurons from XBP1 and CHOP gene deleted mice were resistant against neurotoxins, while those from ATF6 exhibited an enhanced susceptibility [31]. The role of ER stress and IRE1 $\alpha$ and the PERK pathways, regulating $\mathrm{XBP} 1$ and $\mathrm{CHOP}$, respectively, warrant further studies in different PD models.

The link between ER stress and PD has also been suggested by studying familial forms of the disease. Parkin is an E3 ubiquitin ligase (Table 1) that in a mutant form induces ER stress with the accumulation of protein aggregates [32]. One target for Parkin action is the Parkin associated endothelin-receptor like receptor (Pael-R), a G-protein-coupled transmembrane protein which when overexpressed accumulates and causes ER stress in dopaminergic neurons [32, 33]. Parkin is important for the normal turnover of dysfunctional mitochondria via selective autophagy (mitophagy) that links ER stress to
( $\alpha$-syn) in the ER (right). Initially the activated UPR signaling is neuroprotective, but prolonged UPR causes ER stress that leads to activation of cell death pathways. MANF as a novel neurotrophic factor in the ER, reduces ER stress and can restore homeostasis and counteract cell death. The precise mechanisms by which $\alpha$-syn induces ER stress and the action of MANF in cells are under investigations

alterations in mitochondrial oxidative phosphorylation and an increased oxidative stress [33].

Defects in vesicle transport are important mechanisms in $\mathrm{PD}$, and mutant $\alpha$-syn was shown to reduce ER to Golgi trafficking and to aggravate ER stress $[34,35]$. A possible mechanism for $\alpha$-syn induced ER stress in dopaminergic neurons was related to the accumulation of toxic $\alpha$-syn oligomers within the ER lumen and binding to chaperones such as Grp78/Bip (see Fig. 1). Recently, $\alpha$-syn was localised to a subdomain of ER called mitochondria-associated endoplasmic reticulum membrane (MAM) that takes part among others in the regulation of calcium and lipid metabolism in the cells $[36,37]$. It was further shown that the disease-causing A30P and A53T mutant $\alpha$-syn is less present in MAMs compared with the wild-type protein suggesting an altered ER-mitochodria cross talk in PD [37]. Along this line it has been reported that drug agonist for the $\sigma$ non-opioid intracellular receptor 1 (Sigma-R1) which is present in MAM can provide neuroprotection in an animal model of PD [38]. Data showed that the SigmaR1 agonist acted partly by increasing the levels of the neurotrophic factors, brain-derived neurotrophic factor (BDNF) and glial cell line-derived neurotrophic factor (GDNF), but additional mechanisms are also possible [38]. Disease-modifying effects of Sigma-R1 agonists have also been observed in other models of neurodegenerative disease including Huntington diseases [39]. Interference with the accumulation of $\alpha$-syn in the ER and modulation protein complexes associated with MAM are attractive targets to consider for further drug development in PD. 


\section{Mitochondria as therapeutic targets in PD}

Mitochondria are power plants producing cellular energy in the form of ATP. These organelles have also important functions in the regulation of cell metabolism, intracellular calcium levels and the intrinsic (mitochondria-dependent) pathway for cell death [40]. Mitochondrial dysfunctions have been linked to the pathogenesis of PD and manifest themselves as an increase in oxidative stress, production of reactive oxygen species (ROS), decreases in OXPHOS (such as complex I) proteins, mutations in mitochondrial DNA, an altered mitochondrial dynamics [3-5]. As shown in familial form of PD by mutations in the PARK genes, Parkin and PINK disturbances in mitochondrial quality control mechanisms and selective autophagy (mitophagy) are important components of the disease [1, 2, 41]. As recently reviewed [42], neuroprotective strategies to target mitochondria in PD have proven to be difficult with many compounds failing in clinical trials, however, other attempts are currently under scrutiny.

Peroxisome proliferator-activated receptor- $\gamma(\operatorname{PPAR} \gamma)$ coactivator- $1 \alpha$ (PGC- $1 \alpha)$ is a master regulator of mitochondrial biogenesis and of genes involved in cell defense against oxidative stress [43-45]. As shown in PGC- $1 \alpha$ gene deleted mice, brain neurons are more vulnerable to oxidative stress, while overexpression of PGC- $1 \alpha$ can be neuroprotective in animal models of PD [45, 46]. A recent meta-analysis of changes observed in postmortem human PD samples identified PGC- $1 \alpha$ as a potential target for disease intervention [47]. However, the mere overexpression of PGC- $1 \alpha$ may be toxic and increase the vulnerability of dopaminergic neurons towards oxidative stress linked to an enhanced mitochondria metabolism [7, 48, 49]. The fine-tuned regulation of endogenous PGC- $1 \alpha$ in neurons by trophic substances and drugs may therefore be a better strategy to pursue [50]. Recent studies have shown that PGC- $1 \alpha$ exists in different isoforms in tissues including brain but the significance of these in PD remains open [51].

PPAR $\gamma$ and PGC- $1 \alpha$ signaling are altered also in other human degenerative diseases such as type-2 diabetes (T2D). Drugs acting on PPAR $\gamma$ such as the thiazolidonediones (glitazones), rosiglitazone and pioglitazone, which are commonly used in the treatment of T2D, may have potentials also for the treatment of PD [52,53]. Results of preclinical studies showed that rosiglitazone protects dopaminergic neurons in animal models of PD, and pioglitazone can improve parkinsonian syndrome in rhesus monkeys [54-56]. The beneficial effects of these drugs were associated with a reduced neuroinflammation and lower levels of pro-inflammatory cytokines produced by microglia cells in the brain $[55,56]$. A recent epidemiological study on people with T2D revealed a lower incidence of PD in patients on glitazone drugs [57]. However, a double blind clinical trial in early PD patients failed to show any improvement of the disease outcome using pioglitazone [58]. These findings are in contrast to previous positive data in preclinical studies raising concerns about how well toxin-induced animal models may recapitulate the course of human PD (see below).

In addition to glitazones, T2D drugs acting through the glucagon-like peptide R1 receptor (GLP-1R) system have been shown to be neuroprotective in PD models as well as in other brain diseases [52, 53, 59]. Most encouragingly, a clinical trial with exenatide, a GLP-1R agonist, given for 12 months to PD patients, showed that the drug favourably influenced motor and cognitive functions of patients with moderate disease [60]. The positive effects of the drug were sustained in the patients even after a period of 12 months not receiving the drug suggesting a diseasemodifying action of exenatide in PD [61]. A confounding factor in the study was the lack of proper placebo controls, and additional clinical trails are required to corroborate the results [61].

Exenatide and other GLP-1R agonist are well tolerated in humans as shown in treatment of T2D [52, 53]. Future trials in PD (Table 2) may benefit from the development of long-acting GLP-1R agonists and other novel pharmacological compounds targeting the GLP-1R signaling system in T2D. It is also important to study the mechanisms of action of GLP-1R agonist in PD and in neuronal cells as these may partly differ from those in non-neuronal cells. It is possible that in the future a multi-therapy using GLP-1R agonist drugs and trophic factors can provide additional benefits in the treatment of PD.

\section{Neuroinflammation and oxidative stress in PD}

Neuroinflammation with the activation of glial cells has for long time been linked to the disease pathology in PD [6264]. Microglia secrete a number of molecules and the proinflammatory cytokines, interleukin- $1 \beta$, interferon- $\gamma$ and tumor necrosis factor alpha (TNF $\alpha)$ as well as nitric oxide (NO) which all can aggravate the disease. Targeting microglia activation and the pro-inflammatory cytokines using drugs or neuroprotective substances is therefore a valid path to consider for therapy. The neuropeptide PACAP displays an immunomodulatory effect in the brain, and some neurotrophic factors may also target microglial cells (Fig. 2). However, the situation is complex and during early stages of brain diseases microglia may actually provide neuroprotection by producing factors such as interleukin-4 (IL-4) and IL-10. It has been suggested that microglia cells are of two types, M1 and M2 cells that play 


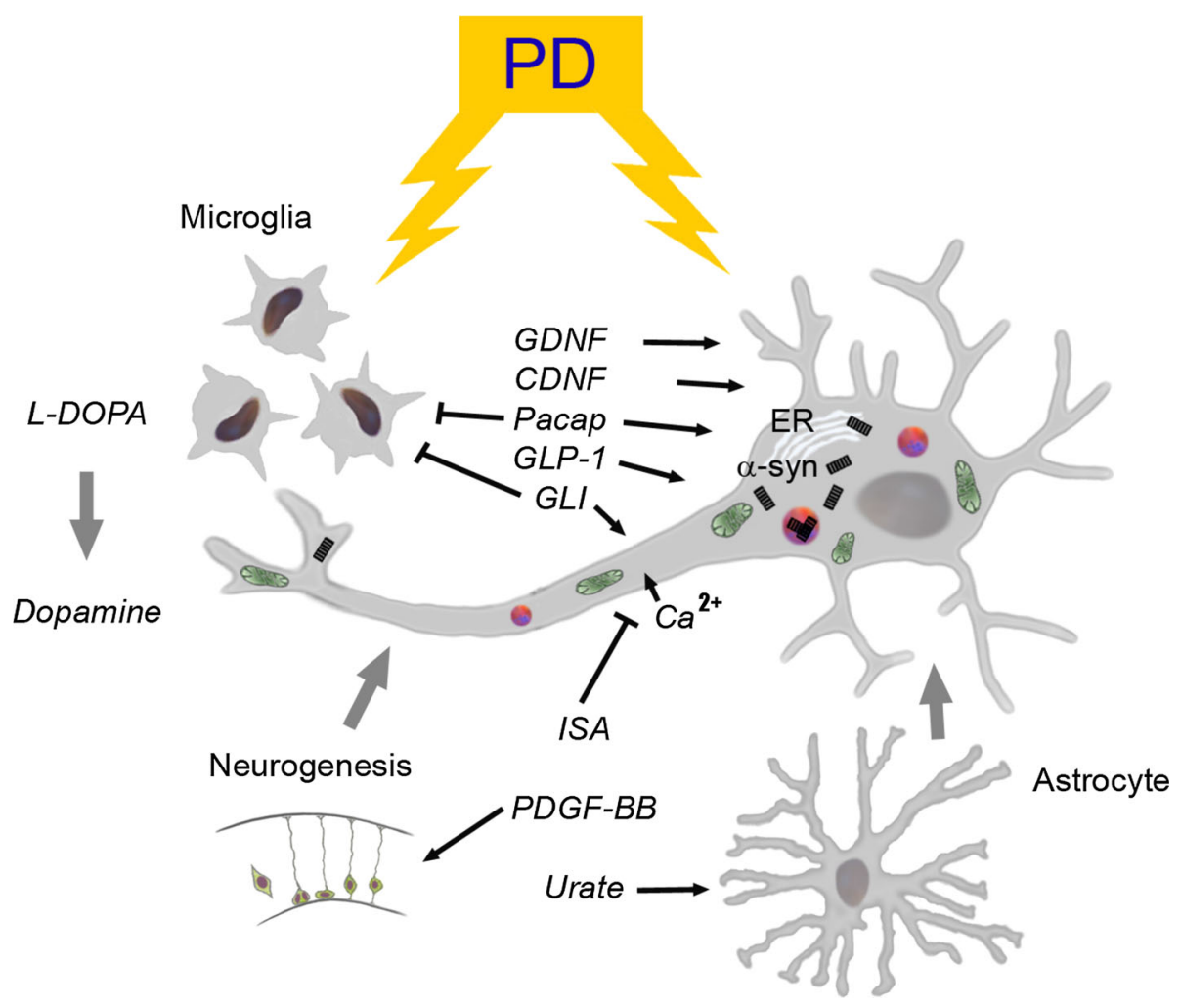

Fig. 2 Neurotrophic approaches and cellular pathways in PD. Pathophysiological events leading to PD are complex and involve several cellular pathways associated with the disease progression as depicted here. L-dopa is used for treatment of PD to restore levels of dopamine in the brain but leads to severe dyskinesia by time. PD is characterized by the presence of cytoplasmic inclusions called Lewy body and Lewy neurites (shown as red circles) that contain ubiquitin and misfolded $\alpha$-synuclein ( $\alpha$-syn) (black rectangles). Currents drugs and disease-modifying substances launched for neuroprotection in PD may act through one or several cellular pathways. Depicted here are the drugs that target dopaminergic neuron firing and calcium influx (isradipine), mitochondria (shown in green) and cell metabolism (glitatzone, GLP-1R agonists), ER stress and inflammatory responses (different drugs, neuropeptides). The neuropeptide Pacap influences cell signaling pathways to increase survival and counteract cell

opposite roles in neuroinflammation depending on the state of activation and the molecules secreted [65]. Previous studies in cell culture and in toxin models of PD provided evidence that IL-10 is protective in dopaminergic neurons, but so far no clinical investigations have been performed [66]. Studies of the interplay between different cytokines and the neuron-glia interactions in the course of PD warrant further studies. The role and plasticity of microglial cells in neuroinflammation have been recently reviewed [67].

Oxidative stress is a major culprit in PD and linked to mitochondrial production of ROS and insufficient antioxidant levels in dopaminergic neurons. Studies using antioxidants such as use of the vitamin $\mathrm{E}$ has not shown promising results in PD. Recent findings indicate that degeneration in neurons. The novel neurotrophic factor, CDNF is both neuroprotective and neurorestorative in animal models of PD. PDGF$\mathrm{BB}$ is able to stimulate neurogenesis and favourably influence dopaminergic neurons, and is well tolerated in PD patients (see text). The GLP-1R agonists used in treatment of type- 2 diabetes have potentials as disease-modifying drugs in PD but better controlled clinical trials are required to confirm data. Elevation of urate concentrations in brain can be neuroprotective via activation of antioxidant pathways through astrocytes (see text). $\alpha$-syn $\alpha$-synuclein, $C D N F$ cerebral dopamine neurotrophic factor, $E R$ endoplasmic reticulum, $G D N F$ glial cell line-derived neurotrophic factor, $G L I$ glitazone, $G L P-1 R$ glucagon-like peptide R1 receptor, $I S A$ isradipine, $P A C A P$ pituitary adenylate cyclase-activating polypeptide, $P D$ Parkinson's disease, $P D G F-B B$ platelet-derived growth factor BB isoform

neuron-astrocyte cross talk plays an important role in the protection of dopaminergic neurons by induction of an antioxidant response in astrocytes via activation of the Nuclear factor erythroid 2-related factor 2 (Nrf2) pathway [68]. Nrf2 is a transcription factor involved in oxidative stress and it increased the expression of various antioxidants in the cell. Epidemiologic studies had shown that the risk of developing PD was lower and the disease progresses slower in people with higher levels of urate in the blood [69]. Increasing urate levels would therefore possibly offer a novel treatment strategy in PD [70]. As a proof-of-principle, a study supplementing PD patients with inosine that can be converted into urate during metabolism was found to increase urate levels significantly without any adverse effects [71]. Interestingly, the higher urate levels slowed 
clinical progression in PD more clearly in women PD patients than in men [72]. A similar sex difference regarding urate levels and clinical outcome was observed in stroke patients [73], and this needs to be taken into account in further trials using uric acid therapies. Currently a phase 3 clinical trial using inosine to elevate urate in PD is planned to answer pertinent questionswhether the treatment can afford neuroprotection and slow disease progression in PD.

\section{Neurotrophic factors in Parkinson's disease}

\section{GDNF family ligands}

GDNF was discovered by its ability to promote the survival and morphological differentiation of dopaminergic neurons and to increase their high-affinity dopamine uptake [74]. GDNF and related growth factor, neurturin (NRTN), artemin and persephin are homodimeric proteins that form a distant group of neurotrophic factors in the transforming growth factor $\beta$ (TGF- $\beta$ ) superfamily [75]. GDNF acts by binding specifically to the GPI-anchored GDNF family receptor alpha 1 (GFR $\alpha 1)$ and then this complex interacts with and activates the receptor tyrosine kinase RET. NRTN primarily binds to its co-receptor GFR $\alpha 2$, but can activate RET also via GFR $\alpha 1[75,76]$. GDNF and NRTN have also alternative receptors NCAM and syndecan-3, but their role for dopamine neurons remains unclear [75, 76].

Studies on gene-deleted animals revealed that GDNF, GFR $\alpha 1$ as well as RET knockout mice die after birth due to the lack of kidney, but have an intact nigrastriatal dopaminergic system, suggesting that GDNF is not crucial for the development of the dopaminergic neurons [75]. Conditional deletions of GDNF, however, have produced conflicting results. Thus one study reported a loss of dopamine neurons [77], whereas the more recent study using three different GDNF deletion approaches found no loss of dopamine neurons in adult midbrain [78]. RET conditional deletion revealed a small loss of midbrain dopamine neurons in aging mice demonstrating that the RET signaling is important for the adult maintenance of these neurons [79].

Preclinical studies have shown that GDNF and NRTN can promote the survival of dopamine neurons in culture as well as protect dopamine neurons in rodent and non-human primate neurotoxin models of PD [76, 80, 81]. Since GDNF is the mostly used neurotrophic factor in animal models of PD, it is often considered as the golden standard for testing other proteins. Experiments using NRTN are fewer, but NRTN was shown to be effective in most of the PD animal models studied [76, 80, 81]. The main difference between GDNF and NRTN is that they use a different
GFR $\alpha$ receptor and that GDNF diffuses better than NRTN in the brain. However, it is clear that GDNF does not exhibit a robust protective effect in all models of PD. Thus, in the severe 6-OHDA model of PD GDNF showed only modest effects, and GDNF also failed to rescue dopamine neurons after overexpression of $\alpha$-syn [76, 81]. This latter may be due to the fact that increased levels of $\alpha$-syn can downregulate the transcription factor Nurr1 leading to a reduced expression of RET [81] that is required for GDNF signaling (see above).

GDNF has been tested in two phase 2 trials on PD patients [76, 82]. In the first trial, GDNF protein was delivered intracerebroventricularly and the treatment had no beneficial effects for the patients [76, 83]. However, GDNF was effective when it was delivered to the caudate putamen in the phase 1 study [84], and thereafter a second phase 2 trial with GDNF protein was conducted. In this trial GDNF was continuously infused to the caudate putamen, but again no clinical benefit was observed as compared to placebo-treated patients [85]. Although, these pioneering studies were less encouraging they gave valuable information and highlighted the importance of basic research to understand the mechanisms for GDNF action in aging brain. Currently, two phases 2 trials with GDNF are ongoing, which partly use a new technology for GDNF protein delivery. Likewise, a GDNF gene therapy phase 1 trial is on its way and during the coming year we should hear exciting news about the results of these trials (Table 2).

Gene therapy has also been used to deliver NTRN to brains of PD patients in two phase 2 trials. Thus, in a clinical trial with 58 PD patients receiving adeno-associated virus serotype 2 expressing NRTN the clinical benefit was statistically significant but modest, and only after 1 year of treatment $[82,86]$. Autopsy data demonstrated that at least one reason for the modest efficacy could be the poor diffusion of NRTN in brain tissue. In a second study, the NRTN-expressing virus was then injected both into the caudate putamen and substantia nigra. Although, this trial did not show a statistically significant benefit overall, it demonstrated efficacy in a small group of patients with early stage PD [82]. This is encouraging and future studies using NRTN and GDNF will benefit from better protein and gene delivery techniques, use of regulated gene therapy vectors, as well as improving the clinical design, and the selection of patient groups for treatment.

\section{CDNF and MANF are novel endoplasmic reticulum located neurotrophic factors for PD}

The moderate effects obtained with GDNF and NRTN in clinical trials have stimulated the search for new growth factors for PD. In 2003, a protein called mesencephalic 
astrocyte-derived neurotrophic factor (MANF) was characterized and demonstrated to promote the survival of embryonic dopamine neurons in culture [87]. Subsequently, a homologous protein called cerebral dopamine neurotrophic factor (CDNF) was discovered and found to be protective for dopamine neurons [88]. CDNF and MANF proteins differ from other neurotrophic factors in amino acid sequence and in 3-dimensional structure, and the proteins are mostly located in the ER [87-89]. Although, the receptors and intracellular signaling pathways triggered by CDNF and MANF are still unknown, it is clear that these factors have a dual mode of action [88, 89]. They can function in the ER interacting with GRP78 and regulating ER stress (Fig. 1), as shown in MANF knockout mice that have chronically active UPR pathways [90]. CDNF was also able to protect dopaminergic neurons against the injury caused by $\alpha$-syn oligomers [91] which induces ER stress (Fig. 1).

In addition to their functions in the ER, CDNF and MANF also act as classical neurotrophic factors on cells by stimulating still unknown plasma membrane receptors and intracellular signaling pathways to protect neurons. Thus, it was shown that CDNF is able to efficiently protect and repair dopamine neurons in rodent 6-OHDA and MPTP models of PD [88, 92], while MANF has so far been tested only in rats using 6-OHDA with beneficial effects [92]. CDNF and MANF diffuse significantly better than GDNF in brain tissue and in the severe rat 6-OHDA model of PD, and CDNF was more efficient than GDNF [93]. Moreover, recent experiments in rhesus monkey using MPTP as a toxin for dopaminergic neurons demonstrated that CDNF is effective in protecting and repairing these neurons by preventing their degeneration and death (unpublished data). CDNF was also shown to improve motor behavior of rhesus monkeys and currently clinical trials with CDNF in PD patients have been planned in 2016.

Taken together CDNF and MANF are new growth factors that are ER-resident protein that may be secreted under certain conditions such as after injury. These factors can protect injured neurons extracellularly by interacting with plasma membrane receptors and by acting inside the cells also modulate UPR and ER stress that contributes to the maintenance and functioning of dopamine neurons.

\section{Other growth factors with neuroprotective potentials in PD}

In addition to GDNF and CDNF-MANF family proteins, many growth factors can protect dopamine neurons in animal models of PD when injected into the brain before the neurotoxin lesion. However, in a clinically more relevant neurorestorative model, when animals are first lesioned with the neurotoxin and only then treated with growth factor, very few factors show neurorestorative activity. Among the proteins that have shown some protective effects after the toxin-induced lesion, one should mention, VEGF-A, VEGF-B, PDGF-BB and some members of the FGF family (see below). VEGF-A enhances the survival of embryonic midbrain dopaminergic neurons in vitro, and is both neuroprotective and neurorestorative in the 6-OHDA rat model of PD [94]. In addition, VEGF-B can stimulate neurogenesis, promote the survival of cultured dopaminergic neurons and protect against 6-OHDA injuries in the rat [94]. Also VEGF-C acts directly on dopamine neurons promoting the survival in vitro and in vivo. However, the in vivo effects of VEGF-C in 6-OHDA animal models of PD were rather modest [94].

Future therapies may include simultaneous use of several growth factors. One very exciting example is the collaboration of GDNF with TGF- $\beta$. Thus, it has been shown that the neurotrophic effect of GDNF in vitro and in vivo requires the presence of TGF- $\beta$ [95]. TGF- $\beta$ induced recruitment of the GDNF receptor, GFR $\alpha 1$ to the plasma membrane, thereby permitting GDNF signaling and neurotrophic effects. The combined effect of GDNF-TGF$\beta$ is robust in rodent models of PD but the efficacy of this has not yet been examined in non-human primates [95].

\section{PDGF}

Platelet-derived growth factor (PDGF) has multitude of functions in different organs including stimulation of cell proliferation [96]. Biologically active PDGF is a dimer that binds to specific tyrosine kinase PDGF receptors on target cells [96]. Different isoforms of PDGF exist in tissues, and the PDGF-BB isoform was shown to be protective in cultured dopaminergic neurons [97]. PDGF-BB was also increased in brain after treatment with 6-OHDA suggesting a compensatory response [98]. Along this line, PDGF-BB injections induced functional recovery and provided neuroprotection of the lesioned nigrastriatal system [99]. Data showed that PDGF-BB might act not directly on dopaminergic neurons, but on neural progenitor and stem cells in the subventricular zone to enhance neurogenesis [99]. Together these results raised the possibility that stimulation of neurogenesis in the brain can enhance recovery and possibly halt the process of cell degeneration in PD. A pilot study with 12 PD patients further showed that administration of PDGF-BB into the brain ventricles for 2 weeks was well tolerated with no obvious side effects [100]. The design of this first trial (the short treatment period, few patients enrolled) was not designed to evaluate the clinical efficacy of PDGF-BB. However, an increase in dopamine transporter (DAT) binding was noted in the putamen of PDGF-BB-treated patient group [100]. Further, 
clinical trials with PD patients are planned (Table 2) to study relevant questions concerning the efficacy, responses and neuroprotective potentials of PDGF-BB in PD [101]. Given PDGF-BB's unique action to stimulate neurogenesis it may be possible to consider a co-treatment with PDGF$\mathrm{BB}$ and other trophic factors or drugs to restore the nigrostriatal system and provide neuroprotection in PD (Fig. 2).

\section{Fibroblast growth factor (FGF) family}

Members of the fibroblast growth factor (FGF) family are secreted proteins that signal via activation of their cognate receptors, consisting of four transmembrane FGF-receptor tyrosine kinases (FGFR1-4). The FGFs have diverse functions ranging from tissue development to metabolism, and some members are also known to display trophic actions on dopaminergic neurons. Thus, FGF20 showed neuroprotection in vitro [102, 103], and attenuated dopaminergic neuron loss and improve behavior in the rat 6-OHDA toxin model of PD [104].

FGF20 can also generate a large number of dopaminergic neurons from different sources of stem cells, including human embryonic stem cells, making it an useful factor for cell-based therapies in PD [105]. There are also reports showing polymorphisms in the regulatory region of the FGF20 gene in PD [106]. However, other studies have reported that FGF20 is probably not a risk factor for PD [107].

In addition to FGF20, several studies have shown that FGF2 can exert protective effects on cultured as well as on midbrain dopaminergic neurons in vivo, and these results have been reviewed [108]. Data thus support a therapeutic potential of FGF20 and FGF2 in PD, but pre-clinical trials have been hampered by the rapid plasma clearance, molecular instability and poor permeability of these factors through the blood-brain barrier.

\section{FGF21}

Fibroblast growth factor 21 (FGF21) is an endocrine growth factor that influences glucose and lipid metabolism in the body [109, 110]. FGF21 acts on targets cells by activating the FGF receptor tyrosine kinase in conjunction with the cofactor $\beta$-klotho [111]. Elevated serum levels of FGF21 are linked to mitochondrial diseases in humans [112]. The biology of FGF21 is complex and the factor can have both systemic and local effects in tissues [109]. FGF21 can pass the blood-brain barrier [113] and may display a good penetration in brain tissue as its lacks the heparin-binding domain present in classical
FGFs [109]. FGF21 is able to extend life span in mice [114], suggesting that it may have beneficial effects on the aging process associated with cell degeneration. Recently, it was shown that FGF21 stimulates mitochondrial functions and PGC- $1 \alpha$ signaling in human dopaminergic neurons [115]. The potential role of FGF21 in regulation of the viability of aging dopaminergic neurons and in models of PD warrants further investigations.

\section{Pituitary adenylate cyclase-activating polypeptide (PACAP)}

PACAP is a member of the secretin/glucagon superfamily [116], and shown to have multiple effects in different tissues, including brain [117-119]. PACAP acts via G-protein-coupled receptors, named PAC1R (specific for PACAP) and the VPAC1 and VPAC2 receptors (shared with the peptide VIP [120]. PACR1 is widely expressed by neurons in the brain including the dopaminergic neurons. PACAP activates both the cAMP/protein kinase A and the phospholipase C/protein kinase $\mathrm{C}$ (PKC) pathways depending on the expression of different PAC1R isoforms [118-120]. The mechanism by which PACAP enhances neuroprotection is complex but related to an increase in specific genes and pathways regulated by cAMP and/or calcium in the neurons [121, 122]. It has also been shown that there is cross talk between PACAP and neurotrophic factor signaling in neurons [123] and this may add to cell protection.

Accumulating evidences support the view that PACAP is neuroprotective on dopaminergic neurons as shown in cell culture experiments [124, 125] and in vivo PD models using the neurotoxins, 6-OHDA and MPTP [126]. Dopaminergic neurons in PACAP-deficient mice are also more susceptible to the toxin paraquat and show changes in microglia and immune responses [127].

PACAP has also a strong anti-inflammatory action, and the peptide can counteract the effects of pro-inflammatory cytokines produced by microglia cells [128, 129]. PACAP is able to cross the blood-brain barrier [130, 131], but the peptide has a short half-life in tissues due to proteolysis. As to possible treatments PACR1 agonists like maxadilan or fragments or derivate of PACAP may therefore be more useful $[119,122]$. In view of the many targets, administration of PACAP may produce side effects that may preclude a long-term treatment with the peptide. For future therapies involving PACAP, it is therefore necessary to carefully consider issues of safety, doses, pharmacological profile, kinetics and the mode of administration of the peptide. 


\section{Clinical trials in PD}

Figure 2 shows a brief summary of recent disease-modifying agents and their known or inferred mechanism of action in PD. Several molecules and trophic factors showing promising neuroprotective actions in preclinical experiments have failed to do so in rigorous clinical trials. These outcomes have been the subject of a recent review [28]. It is foreseen that an increased understanding of mechanisms underlying PD together with the development of better animal models reflecting the complexity of human PD can help to reveal novel targets for intervention. Regarding trophic factors, treatments with GDNF or NRTN have produced mixed results raising questions about doses, methods of delivery and tissue penetration of the factors. The possible beneficial role of GDNF in PD is being further explored (Table 2). The novel dopaminergic factor CDNF showed positive results in preclinical models of PD, and CDNF is currently studied in rhesus monkey PD model and entering clinical trials. The first experiments with PDGF-BB infused to human brains showed a good tolerability in PD patients encouraging further clinical trials using this growth factor (Table 2). GLP-1 agonists primarily used for the treatment of T2D have also shown beneficial effects in preclinical models of PD. Recently, an open-label clinical study using exenatide revealed a sustained positive effect in PD patients with improvement of clinical scoring suggesting a disease-modifying effect of the drug (Table 2). Currently, further studies are underway to confirm these results using exenatide and also other GLP-1 agonists in PD. At the same time, more preclinical work is required to better understand the mechanisms of action of these compounds in providing neuroprotection and promote functional recovery in PD patients. In addition to drugs and growth factors immunotherapies targeting $\alpha$ syn may show potential benefits in the disease, but this has to await the first clinical trial with PD patients (Table 2).

\section{Conclusions and future prospective}

PD has a complex etiology with contributions of genetic and environmental risk factors. Patients afflicted by the disease show both motor and non-motor symptoms and the current treatments with dopamine replacement using L-dopa and other dopamine agonists target mainly the former. No drugs or therapies are currently available to efficiently target the neurodegenerative process or slow disease progression in PD. Recent studies on the pathophysiology and genetic causes of PD have raised hopes that it may be possible in the future to design and tailor-made disease-modifying therapies and neuroprotective agents in
PD. However to accomplish this more preclinical work into the mechanisms of neuroprotection is required combined with controlled and well-designed clinical trials of promising drugs and disease-modifying substances in PD patients. Studies on-going to identify novel biomarkers for PD are also important (see www.clinicaltrials.gov) and will be helpful for early diagnosis and for treatment, and for follow-up of outcomes of clinical trials in PD. For effective therapies, the stratification of PD patient according to etiology (familial and sporadic forms) is also crucial as these may vary between patient groups. Depending on the severity and state of the disease, PD patients may require a different treatment approach for example with regard to targeting neuroinflammation that depending on the functional state of microglia may be a friend or a foe in the disease. It is also possible that not one single but a combined therapy is required to effectively combat cell degeneration and restore neuronal functions in PD. The current research on neuroprotective agents and diseasemodifying drugs in PD has generated promising data that bears potentials for a better treatment of patients afflicted by this dreadful disease.

Acknowledgments The work in the groups is supported by Academy of Finland (DL, MS), Jane and Aatos Erkko Foundation (MS), Michael J Fox Foundation for Parkinson's Research (MS), Finnish Parkinson Foundation (DL, JM), Minerva Foundation (DL, JM), University of Helsinki (DL, JM, OE, MS) and by Progetti di Ateneo, University of Palermo (VD, GM, NB).

\section{References}

1. Klein C, Westenberger A (2012) Genetics of Parkinson's disease. Cold Spring Harb Perspect Med. 2:a008888

2. Mullin S, Schapira A (2015) The genetics of Parkinson's disease. Br Med Bull 114:39-52

3. Henchcliffe C, Beal MF (2008) Mitochondrial biology and oxidative stress in Parkinson disease pathogenesis. Nat Clin Pract Neurol 4:600-609

4. Gupta A, Dawson VL, Dawson TM (2008) What causes cell death in Parkinson's disease? Ann Neurol 64(Suppl 2):S3-S15

5. Perier C, Vila M (2012) Mitochondrial biology and Parkinson's disease. Cold Spring Harb Perspect Med 2:a009332

6. Guzman JN, Sanchez-Padilla J, Wokosin D, Kondapalli J, Ilijic E, Schumacker PT, Surmeier DJ (2010) Oxidant stress evoked by pacemaking in dopaminergic neurons is attenuated by DJ-1. Nature 468:696-700

7. Pacelli C, Giguere N, Bourque M-J, Lévesque M, Slack RS, Trudeau LE (2015) Elevated mitochondrial mioenergetics and axonal arborization size are key contributors to the vulnerability of dopamine neurons. Curr Biol 25:2349-2360. doi:10.1016/j. cub.2015.07.050

8. Goedert M, Spillantini MG, Del Tredici K, Braak H (2013) 100 years of Lewy pathology. Nat Rev Neurol 9:13-24

9. Brundin P, Atkin G, Lamberts JT (2015) Basic science breaks through: new therapeutic advances in Parkinson's disease. Mov Disord 30:1521-1527. doi:10.1002/mds.26332 
10. Betzer C, Movius AJ, Shi M, Gai WP, Zhang J, Jensen PH (2015) Identification of synaptosomal proteins binding to monomeric and oligomeric $\alpha$-synuclein. PLoS One 10:e0116473

11. Cuervo AM, Stefanis L, Fredenburg R, Lansbury PT, Sulzer D (2004) Impaired degradation of mutant alpha-synuclein by chaperone-mediated autophagy. Science 305:1292-1295

12. Chu Y, Dodiya H, Aebischer P, Olanow CW, Kordower JH (2009) Alterations in lysosomal and proteasomal markers in Parkinson's disease: relationship to alpha-synuclein inclusions. Neurobiol Dis 35:385-398

13. Decressac M, Mattsson B, Weikop P, Lundblad M, Jakobsson J, Björklund A (2013) TFEB-mediated autophagy rescues midbrain dopamine neurons from $\alpha$-synuclein toxicity. Proc Natl Acad Sci U S A 110:E1817-E1826

14. Schapira AH (2015) Glucocerebrosidase and Parkinson disease: recent advances. Mol Cell Neurosci 66:37-42

15. Gegg ME, Burke D, Heales SJ, Cooper JM, Hardy J, Wood NW, Schapira AH (2012) Glucocerebrosidase deficiency in substantia nigra of parkinson disease brains. Ann Neurol 72:455-463

16. Gegg ME, Sweet L, Wang BH, Shihabuddin LS, Sardi SP, Schapira AH (2015) No evidence for substrate accumulation in Parkinson brains with GBA mutations. Mov Disord 30:1085-1089

17. Cullen V, Sardi SP, Ng J, Xu YH, Sun Y, Tomlinson JJ, Kolodziej P, Kahn I, Saftig P, Woulfe J, Rochet JC, Glicksman MA, Cheng SH, Grabowski GA, Shihabuddin LS, Schlossmacher MG (2011) Acid $\beta$-glucosidase mutants linked to Gaucher disease, Parkinson disease, and Lewy body dementia alter $\alpha$-synuclein processing. Ann Neurol 69:940-953

18. Braak H, Del Tredici K, Rüb U, de Vos RA, Jansen Steur EN, Braak E (2003) Staging of brain pathology related to sporadic Parkinson's disease. Neurobiol Aging 24:197-211

19. Braak H, Bohl JR, Müller CM, Rüb U, de Vos RA, Del Tredici K (2006) Stanley Fahn Lecture 2005: the staging procedure for the inclusion body pathology associated with sporadic Parkinson's disease reconsidered. Mov Disord 21:2042-2051

20. Dehay B, Vila M, Bezard E, Brundin P, Kordower JH (2015) Alpha-synuclein propagation: New insights from animal models. Mov Disord. doi: $10.1002 / \mathrm{mds} .26370$

21. Scheperjans F, Aho V, Pereira PA, Koskinen K, Paulin L, Pekkonen E, Haapaniemi E, Kaakkola S, Eerola-Rautio J, Pohja M, Kinnunen E, Murros K, Auvinen P (2015) Gut microbiota are related to Parkinson's disease and clinical phenotype. Mov Disord 30:350-358

22. Schapira AH, Olanow CW, Greenamyre JT, Bezard E (2014) Slowing of neurodegeneration in Parkinson's disease and Huntington's disease: future therapeutic perspectives. Lancet 384:545-555

23. Lindström V, Ihse E, Fagerqvist T, Bergström J, Nordström E, Möller C, Lannfelt L, Ingelsson M (2014) Immunotherapy targeting $\alpha$-synuclein, with relevance for future treatment of Parkinson's disease and other Lewy body disorders. Immunotherapy 6:141-153

24. Walter P, Ron D (2011) The unfolded protein response: from stress pathway to homeostatic regulation. Science 334:1081-1086

25. Lindholm D, Wootz H, Korhonen L (2006) ER stress and neurodegenerative diseases. Cell Death Differ 13:385-392

26. Hetz C, Mollereau B (2014) Disturbance of endoplasmic reticulum proteostasis in neurodegenerative diseases. Nat Rev Neurosci 15:233-249

27. Ryu EJ, Harding HP, Angelastro JM, Vitolo OV, Ron D, Greene LA (2002) Endoplasmic reticulum stress and the unfolded protein response in cellular models of Parkinson's disease. J Neurosci 22:10690-10698
28. Baek JH, Whitfield D, Howlett D, Francis P, Bereczki E, Ballard C, Hortobágyi T, Attems J, Aarsland D (2015) Unfolded protein response is activated in Lewy body dementias. Neuropathol Appl Neurobiol. doi:10.1111/nan.12260

29. Chung CY, Khurana V, Auluck PK, Tardiff DF, Mazzulli JR, Soldner F, Baru V, Lou Y, Freyzon Y, Cho S, Mungenast AE, Muffat J, Mitalipova M, Pluth MD, Jui NT, Schüle B, Lippard SJ, Tsai LH, Krainc D, Buchwald SL, Jaenisch R, Lindquist S (2013) Identification and rescue of $\alpha$-synuclein toxicity in Parkinson patient-derived neurons. Science 342:983-987

30. Mercado G, Valdés P, Hetz C (2013) An ERcentric view of Parkinson's disease. Trends Mol Med 19:165-715

31. Mercado G, Castillo V, Vidal R, Hetz C (2015) ER proteostasis disturbances in Parkinson's disease: novel insights. Front Aging Neurosci. 7:39

32. Imai Y, Takahashi R (2004) How do Parkin mutations result in neurodegeneration? Curr Opin Neurobiol 14:384-389

33. Kitao Y, Imai Y, Ozawa K, Kataoka A, Ikeda T, Soda M, Nakimawa K, Kiyama H, Stern DM, Hori O, Wakamatsu K, Ito S, Itohara S, Takahashi R, Ogawa S (2007) Pael receptor induces death of dopaminergic neurons in the substantia nigra via endoplasmic reticulum stress and dopamine toxicity, which is enhanced under condition of parkin inactivation. Hum Mol Genet 16:50-60

34. Thayanidhi N, Helm JR, Nycz DC, Bentley M, Liang Y, Hay JC (2010) Alpha-synuclein delays endoplasmic reticulum (ER)-toGolgi transport in mammalian cells by antagonizing ER/Golgi SNAREs. Mol Biol Cell 21:1850-1863

35. Colla E, Coune P, Liu Y, Pletnikova O, Troncoso JC, Iwatsubo T, Schneider BL, Lee MK (2012) Endoplasmic reticulum stress is important for the manifestations of $\alpha$-synucleinopathy in vivo. J Neurosci 32:3306-3320

36. Hayashi T, Rizzuto R, Hajnoczky G, Su TP (2009) MAM: more than just a housekeeper. Trends Cell Biol 19:81-88

37. Guardia-Laguarta C, Area-Gomez E, Rüb C, Liu Y, Magrané J, Becker D, Voos W, Schon EA, Przedborski S (2014) $\alpha$-Synuclein is localized to mitochondria-associated ER membranes. J Neurosci 34:249-259

38. Francardo V, Bez F, Wieloch T, Nissbrandt H, Ruscher K, Cenci MA (2014) Pharmacological stimulation of sigma-1 receptors has neurorestorative effects in experimental parkinsonism. Brain 137:1998-2014

39. Hyrskyluoto A, Pulli I, Törnqvist K, Ho TH, Korhonen L, Lindholm D (2013) Sigma-1 receptor agonist PRE084 is protective against mutant huntingtin-induced cell degeneration: involvement of calpastatin and the NF- $\kappa \mathrm{B}$ pathway. Cell Death Dis 4:e646

40. Nunnari J, Suomalainen A (2012) Mitochondria: in sickness and in health. Cell 148:1145-1159

41. Rugarli EI, Langer T (2012) Mitochondrial quality control: a matter of life and death for neurons. EMBO J 31:1336-1349

42. Kalia LV, Kalia SK, Lang AE (2015) Disease-modifying strategies for Parkinson's disease. Mov Disord. doi:10.1002/ mds. 26354

43. Puigserver P, Spiegelman BM (2003) Peroxisome proliferatoractivated receptor-gamma coactivator 1 alpha (PGC-1 alpha): transcriptional coactivator and metabolic regulator. Endocr Rev 24:78-90

44. Houten SM, Auwerx J (2004) PGC-1alpha: turbocharging mitochondria. Cell 119:5-7

45. St-Pierre J, Drori S, Uldry M, Silvaggi JM, Rhee J, Jäger S, Handschin C, Zheng K, Lin J, Yang W, Simon DK, Bachoo R, Spiegelman BM (2006) Suppression of reactive oxygen species and neurodegeneration by the PGC-1 transcriptional coactivators. Cell 127:397-408 
46. Mudò G, Mäkelä J, Di Liberto V, Tselykh TV, Olivieri M, Piepponen P, Eriksson O, Mälkiä A, Bonomo A, Kairisalo M, Aguirre JA, Korhonen L, Belluardo N, Lindholm D (2012) Transgenic expression and activation of PGC- $1 \alpha$ protect dopaminergic neurons in the MPTP mouse model of Parkinson's disease. Cell Mol Life Sci 69:1153-1165

47. Zheng B, Liao Z, Locascio JJ, Lesniak KA, Roderick SS, Watt ML, Eklund AC, Zhang-James Y, Kim PD, Hauser MA, Grünblatt E, Moran LB, Mandel SA, Riederer P, Miller RM, Federoff HJ, Wüllner U, Papapetropoulos S, Youdim MB, Cantuti-Castelvetri I, Young AB, Vance JM, Davis RL, Hedreen JC, Adler CH, Beach TG, Graeber MB, Middleton FA, Rochet JC, Scherzer CR, Global PD Gene Expression (GPEX) Consortium (2010) PGC-1 $\alpha$, a potential therapeutic target for early intervention in Parkinson's disease. Sci Transl Med 2: 52ra73

48. Ciron C, Lengacher S, Dusonchet J, Aebischer P, Schneider BL (2012) Sustained expression ofPGC-1a in the rat nigrostriatal system selectively impairs dopaminergic function. Hum Mol Genet 21:1861-1876

49. Clark J, Silvaggi JM, Kiselak T, Zheng K, Clore EL, DaiY Bass CE, Simon DK (2012) Pgc-1a overexpression downregulates Pitx3 and increases susceptibility to MPTP toxicity associated with decreased Bdnf. PLoS One 7:e48925

50. Lindholm D, Eriksson O, Makela J, Belluardo N, Korhonen L (2012) PGC-1alpha: a master gene that is hard to master. Cell Mol Life Sci 69:2465-2468

51. Soyal SM, Felder TK, Auer S, Hahne P, Oberkofler H, Witting A, Paulmichl M, Landwehrmeyer GB, Weydt P, Patsch W, Network European Huntington Disease (2012) A greatly extended PPARGC1A genomic locus encodes several new brain-specific isoforms and influences Huntington disease age of onset. Hum Mol Genet 21:3461-3473

52. Aviles-Olmos I, Limousin P, Lees A, Foltynie T (2013) Parkinson's disease, insulin resistance and novel agents of neuroprotection. Brain 136:374-384

53. Patrone C, Eriksson O, Lindholm D (2014) Diabetes drugs and neurological disorders: new views and therapeutic possibilities. Lancet Diabetes Endocrinol 2:256-262

54. Schintu N, Frau L, Ibba M, Caboni P, Garau A, Carboni E, Carta AR (2009) PPAR-gamma-mediated neuroprotection in a chronic mouse model of Parkinson's disease. Eur J Neurosci 29:954-963

55. Carta AR, Frau L, Pisanu A, Wardas J, Spiga S, Carboni E (2011) Rosiglitazone decreases peroxisome proliferator receptor-gamma levels in microglia and inhibits TNF-alpha production: new evidences on neuroprotection in a progressive Parkinson's disease model. Neuroscience 194:250-261

56. Swanson CR, Joers V, Bondarenko V, Brunner K, Simmons HA, Ziegler TE, Kemnitz JW, Johnson JA, Emborg ME (2011) The PPAR- $\gamma$ agonist pioglitazone modulates inflammation and induces neuroprotection in parkinsonian monkeys. J Neuroinflammation 8:91. doi:10.1186/1742-2094-8-91

57. Brauer R, Bhaskaran K, Chaturvedi N, Dexter DT, Smeeth L, Douglas I (2015) Glitazone treatment and incidence of Parkinson's disease among people with diabetes: a retrospective cohort study. PLoS Med 12:e1001854

58. NINDS Exploratory Trials in Parkinson Disease (NET-PD) FSZONE Investigators (2015) Pioglitazone in early Parkinson's disease: a phase 2, multicentre, double-blind, randomised trial. Lancet Neurol 14:795-803

59. Li Y, Perry T, Kindy MS, Harvey BK, Tweedie D, Holloway HW, Powers K, Shen H, Egan JM, Sambamurti K, Brossi A, Lahiri DK, Mattson MP, Hoffer BJ, Wang Y, Greig NH (2009) GLP-1 receptor stimulation preserves primary cortical and dopaminergic neurons in cellular and rodent models of stroke and Parkinsonism. Proc Natl Acad Sci USA 106:1285-1290
60. Aviles-Olmos I, Dickson J, Kefalopoulou Z, Djamshidian A, Ell P, Soderlund T, Whitton P, Wyse R, Isaacs T, Lees A, Limousin $\mathrm{P}$, Foltynie $\mathrm{T}$ (2013) Exenatide and the treatment of patients with Parkinson's disease. J Clin Invest 123:2730-2736

61. Aviles-Olmos I, Dickson J, Kefalopoulou Z, Djamshidian A, Kahan J, Ell P, Whitton P, Wyse R, Isaacs T, Lees A, Limousin P, Foltynie T (2014) Motor and cognitive advantages persist 12 months after exenatide exposure in Parkinson's disease. J Parkinsons Dis 4:337-344

62. McGeer PL, Itagaki S, Boyes BE, McGeer EG (1988) Reactive microglia are positive for HLA-DR in the substantia nigra of Parkinson's and Alzheimer's disease brains. Neurology 38:1285-1291

63. Gerhard A, Pavese N, Hotton G, Turkheimer F, Es M, Hammers A, Eggert K, Oertel W, Banati RB, Brooks DJ (2006) In vivo imaging of microglial activation with [11C](R)-PK11195 PET in idiopathic Parkinson's disease. Neurobiol Dis 21:404-412

64. Ouchi Y, Yagi S, Yokokura M, Sakamoto M (2009) Neuroinflammation in the living brain of Parkinson's disease. Parkinsonism Relat Disord 15:S200-S204

65. Sica A, Mantovani A (2012) Macrophage plasticity and polarization: in vivo veritas. J Clin Invest. 122:787-795

66. Kwilasz AJ, Grace PM, Serbedzija P, Maier SF, Watkins LR (2015) The therapeutic potential of interleukin-10 in neuroimmune diseases. Neuropharmacology 96:55-69

67. Fernandes A, Miller-Fleming L, Pais TF (2014) Microglia and inflammation: conspiracy, controversy or control? Cell Mol Life Sci 71:3969-3985

68. Bakshi R, Zhang H, Logan R, Joshi I, Xu Y, Chen X, Schwarzschild MA (2015) Neuroprotective effects of urate are mediated by augmenting astrocytic glutathione synthesis and release. Neurobiol Dis. doi:10.1016/j.nbd.2015.08.022

69. Weisskopf MG, O'Reilly E, Chen H, Schwarzschild MA, Ascherio A (2007) Plasma urate and risk of Parkinson's disease. Am J Epidemiol 166:561-567

70. Ascherio A, LeWitt PA, Xu K, Eberly S, Watts A, Matson WR, Marras C, Kieburtz K, Rudolph A, Bogdanov MB, Schwid SR, Tennis M, Tanner CM, Beal MF, Lang AE, Oakes D, Fahn S, Shoulson I, Schwarzschild MA, Parkinson Study Group DATATOP Investigators (2009) Urate as a predictor of the rate of clinical decline in Parkinson disease. Arch Neurol 66:1460-1468

71. Parkinson Study Group SURE-PD Investigators, Schwarzschild MA, Ascherio A, Beal MF, Cudkowicz ME, Curhan GC, Hare JM, Hooper DC, Kieburtz KD, Macklin EA, Oakes D, Rudolph A, Shoulson I, Tennis MK, Espay AJ, Gartner M, Hung A, Bwala G, Lenehan R, Encarnacion E, Ainslie M, Castillo R, Togasaki D, Barles G, Friedman JH, Niles L, Carter JH, Murray M, Goetz CG, Jaglin J, Ahmed A, Russell DS, Cotto C, Goudreau JL, Russell D, Parashos SA, Ede P, Saint-Hilaire MH, Thomas CA, James R, Stacy MA, Johnson J, Gauger L, Antonelle de Marcaida J, Thurlow S, Isaacson SH, Carvajal L, Rao J, Cook M, Hope-Porche C, McClurg L, Grasso DL, Logan R, Orme C, Ross T, Brocht AF, Constantinescu R, Sharma S, Venuto C, Weber J, Eaton K (2014) Inosine to increase serum and cerebrospinal fluid urate in Parkinson disease: a randomized clinical trial. JAMA Neurol 71:141-150

72. Schwarzschild MA, Macklin EA, Ascherio A, Parkinson Study Group SURE-PD Investigators (2014) Urate and neuroprotection trials. Lancet Neurol 13:758

73. Chamorro A, Amaro S, Castellanos M, Segura T, Arenillas J, Martí-Fábregas J, Gállego J, Krupinski J, Gomis M, Cánovas D, Carné X, Deulofeu R, Román LS, Oleaga L, Torres F, Planas AM, Investigators URICO-ICTUS (2014) Safety and efficacy of uric acid in patients with acute stroke (URICO-ICTUS): a 
randomised, double-blind phase $2 \mathrm{~b} / 3$ trial. Lancet Neurol 13:453-460

74. Lin LF, Doherty DH, Lile JD, Bektesh S, Collins F (1993) GDNF: a glial cell line-derived neurotrophic factor for midbrain dopaminergic neurons. Science 260:1130-1132

75. Airaksinen MS, Saarma M (2002) The GDNF family: signalling, biological functions and therapeutic value. Nat Rev Neurosci 3:383-394

76. Domanskyi A, Saarma M, Airavaara M (2015) Prospects of neurotrophic factors for Parkinson's disease: comparison of protein and gene therapy. Hum Gene Ther 26:550-559

77. Pascual A, Hidalgo-Figueroa M, Piruat JI, Pintado CO, GómezDíaz R, López-Barneo J (2008) Absolute requirement of GDNF for adult catecholaminergic neuron survival. Nat Neurosci 11:755-761

78. Kopra J, Vilenius C, Grealish S, Harma M-A, Varendi K, Lindholm J, Castren E, Voikar V, Bjorklund A, Piepponen TP, Saarma $\mathrm{M}$, Andressoo J-O (2015) GDNF is not required for catecholaminergic neuron survival in vivo. Nat Neurosci 18:319-322

79. Kramer ER, Aron L, Ramakers GM, Seitz S, Zhuang X, Beyer K, Smidt MP, Klein R (2007) Absence of Ret signaling in mice causes progressive and late degeneration of the nigrostriatal system. PLoS Biol 5:e39

80. Aron L, Klein R (2011) Repairing the parkinsonian brain with neurotrophic factors. Trends Neurosci 34:88-100

81. Decressac M, Kadkhodaei B, Mattsson B, Laguna A, Perlmann T, Björklund A (2012) $\alpha$-Synuclein-induced down-regulation of Nurr1 disrupts GDNF signaling in nigral dopamine neurons. Sci Transl Med 4:163ra156

82. Bartus RT, Weinberg MS, Samulski RJ (2014) Parkinson's disease gene therapy: successby design meets failure by efficacy. Mol Ther 22:487-497

83. Nutt JG, Burchiel KJ, Comella CL, Jankovic J, Lang AE, Laws ER Jr, Lozano AM, Penn RD, Simpson RK Jr, Stacy M, Wooten GF; ICV GDNF Study Group (2003) Implanted intracerebroventricular. Glial cell line-derived neurotrophic factor. Randomized, double-blind trial of glial cell line-derived neurotrophic factor (GDNF) in PD. Neurology 6:69-73

84. Gill SS, Patel NK, Hotton GR, O'Sullivan K, McCarter R, Bunnage M, Brooks DJ, Svendsen CN, Heywood P (2003) Direct brain infusion of glial cell line-derived neurotrophic factor in Parkinson disease. Nat Med 9:589-595

85. Lang AE, Gill S, Patel NK, Lozano A, Nutt JG, Penn R, Brooks DJ, Hotton G, Moro E, Heywood P, Brodsky MA, Burchiel K, Kelly P, Dalvi A, Scott B, Stacy M, Turner D, Wooten VG, Elias WJ, Laws ER, Dhawan V, Stoessl AJ, Matcham J, Coffey RJ, Traub M (2006) Randomized controlled trial of intraputamenal glial cell line-derived neurotrophic factor infusion in Parkinson disease. Ann Neurol 59:459-466

86. Marks WJ Jr, Bartus RT, Siffert J, Davis CS, Lozano A, Boulis N, Vitek J, Stacy M, Turner D, Verhagen L, Bakay R, Watts R, Guthrie B, Jankovic J, Simpson R, Tagliati M, Alterman R, Stern M, Baltuch G, Starr PA, Larson PS, Ostrem JL, Nutt J, Kieburtz K, Kordower JH, Olanow CW (2010) Gene delivery of AAV2-neurturin for Parkinson's disease: a double-blind, randomised, controlled trial. Lancet Neurol 9:1164-1172

87. Petrova P, Raibekas A, Pevsner J, Vigo N, Anafi M, Moore MK, Peaire AE, Shridhar V, Smith DI, Kelly J, Durocher Y, Commissiong JW (2003) MANF: a new mesencephalic, astrocytederived neurotrophic factor with selectivity for dopaminergic neurons. J Mol Neurosci 20:173-188

88. Lindholm P, Voutilainen MH, Laurén J, Peränen J, Leppänen V-M, Andressoo J-O, Lindahl M, Janhunen S, Kalkkinen N, Timmusk T, Tuominen RK, Saarma M (2007) Novel neurotrophic factor $\mathrm{CDNF}$ protects and rescues midbrain dopaminergic neurons in vivo. Nature 448:73-77
89. Lindholm P, Saarma M (2010) Novel CDNF/MANF family of neurotrophic factors. Dev Neurobiol 70:360-371

90. Lindahl M, Danilova T, Palm E, Pulkkila P, Voikar V, Hakonen E, Ustinov J, Andressoo J-O, Harvery B, Otonkoski T, Rossi J, Saarma M (2014) MANF is indispensable for the proliferation and survival of pancreatic $\beta$-cells. Cell Reports 7:366-375

91. Latge C, Cabral KM, Johanson L, Romão LF, Herrmann T, Almeida MS, Foguel D (2015) The solution structure and dynamics of full-length human cerebral dopamine neurotrophic factor and its neuroprotective role against $\alpha$-synuclein oligomers. J Biol Chem 290:20527-20540

92. Voutilainen MH, Bäck S, Pörsti E, Toppinen L, Lindgren L, Lindholm P, Peränen J, Saarma M, Tuominen RK (2009) Mesencephalic astrocyte-derived neurotrophic factor is neurorestorative in rat model of Parkinson's disease. J Neurosci 29:9651-9659

93. Voutilainen MH, Bäck S, Peränen J, Lindholm P, Raasmaja A, Männistö PT, Saarma M, Tuominen RK (2011) Chronic infusion of CDNF prevents 6-OHDA-induced deficits in a rat model of Parkinson's disease. Exp Neurol 228:99-108

94. Piltonen M, Planken A, Leskelä $\mathrm{O}$, Myöhänen TT, Hänninen AL, Auvinen P, Alitalo K, Andressoo JO, Saarma M, Männistö PT (2011) Vascular endothelial growth factor $\mathrm{C}$ acts as a neurotrophic factor for dopamine neurons in vitro and in vivo. Neuroscience 192:550-563

95. Peterziel H, Unsicker K, Krieglstein K (2002) TGFbeta induces GDNF responsiveness in neurons by recruitment of GFRalpha1 to the plasma membrane. J Cell Biol 59:157-167

96. Heldin CH, Westermark B (1999) Mechanism of action and in vivo role of platelet-derived growth factor. Physiol Rev 79:1283-1316

97. Pietz K, Odin P, Funa K, Lindvall O (1996) Protective effect of platelet-derived growth factor against 6-hydroxydopamine-induced lesion of rat dopaminergic neurons in culture. Neurosci Lett 204:101-104

98. Funa K, Yamada N, Brodin G, Pietz K, Ahgren A, Wictorin K, Lindvall O, Odin P (1996) Enhanced synthesis of plateletderived growth factor following injury induced by 6-hydroxydopamine in rat brain. Neuroscience 74:825-833

99. Zachrisson O, Zhao M, Andersson A, Dannaeus K, Häggblad J, Isacson R, Nielsen E, Patrone C, Rönnholm H, Wikstrom L, Delfani K, McCormack AL, Palmer T, Di Monte DA, Hill MP, Janson Lang AM, Haegerstrand A (2011) Restorative effects of platelet derived growth factor-BB in rodent models of Parkinson's disease. J Parkinsons Dis 1:49-63

100. Paul G, Zachrisson O, Varrone A, Almqvist P, Jerling M, Lind G, Rehncrona S, Linderoth B, Bjartmarz H, Shafer LL, Coffey R, Svensson M, Mercer KJ, Forsberg A, Halldin C, Svenningsson $\mathrm{P}$, Widner $\mathrm{H}$, Frisén J, Pålhagen $\mathrm{S}$, Haegerstrand A (2015) Safety and tolerability of intracerebroventricular PDGFBB in Parkinson's disease patients. J Clin Invest. 125:1339-1346

101. Foltynie T (2015) Can Parkinson's disease be cured by stimulating neurogenesis? J Clin Invest 125:978-980

102. Ohmachi S, Mikami T, Konishi M, Miyake A, Itoh N (2003) Preferential neurotrophic activity of fibroblast growth factor-20 for dopaminergic neurons through fibroblast growth factor receptor-1c. J Neurosci Res 72:436-443

103. Murase S, McKay RD (2006) A specific survival response in dopamine neurons at most risk in Parkinson's disease. J Neurosci 26:9750-9760

104. Sleeman IJ, Boshoff EL, Duty S (2012) Fibroblast growth factor-20 protects against dopamine neuron loss in vitro and provides functional protection in the 6-hydroxydopamine-lesioned rat model of Parkinson's disease. Neuropharmacology 63:1268-1277 
105. Correia AS, Anisimov SV, Li JY, Brundin P (2008) Growth factors and feeder cells promote differentiation of human embryonic stem cells into dopaminergic neurons: a novel role for fibroblast growth factor-20. Front Neurosci 2:26-34

106. van der Walt JM, Noureddine MA, Kittappa R, Hauser MA, Scott WK, McKay R, Zhang F, Stajich JM, Fujiwara K, Scott BL, Pericak-Vance MA, Vance JM, Martin ER (2004) Fibroblast growth factor 20 polymorphisms and haplotypes strongly influence risk of Parkinson disease. Am J Hum Genet 74:1121-1127

107. Xu X, Wang N, Xu H, Xie A, Jiang H, Xie J (2013) Fibroblast growth factor 20 polymorphism in sporadic Parkinson's disease in Northern Han Chinese. J Clin Neurosci 20:1588-1590

108. Grothe C, Timmer M (2007) The physiological and pharmacological role of basic fibroblast growth factor in the dopaminergic nigrostriatal system. Brain Res Rev 54:80-91

109. Cantó C, Auwerx J (2012) Cell biology. FGF21 takes a fat bite. Science 336:675-676

110. Zhang F, Yu L, Lin X, Cheng P, He L, Li X, Lu X, Tan Y, Yang $\mathrm{H}$, Cai L, Zhang C (2015) Minireview: roles of fibroblast growth factors 19 and 21 in metabolic regulation and chronic diseases. Mol Endocrinol 26:me20151155

111. Kuro-o M (2008) Endocrine FGFs and Klothos: emerging concepts. Trends Endocrinol Metab 19:239-245

112. Suomalainen A, Elo JM, Pietiläinen KH, Hakonen AH, Sevastianova K, Korpela M, Isohanni P, Marjavaara SK, Tyni T, Kiuru-Enari S, Pihko H, Darin N, Ounap K, Kluijtmans LA, Paetau A, Buzkova J, Bindoff LA, Annunen-Rasila J, Uusimaa J, Rissanen A, Yki-Järvinen H, Hirano M, Tulinius M, Smeitink J, Tyynismaa H (2011) FGF-21 as a biomarker for musclemanifesting mitochondrial respiratory chain deficiencies: a diagnostic study. Lancet Neurol 10:806-818

113. Hsuchou H, Pan W, Kastin AJ (2007) The fasting polypeptide FGF21 can enter brain from blood. Peptides 28:2382-2386

114. Zhang Y, Xie Y, Berglund ED, Coate KC, He TT, Katafuchi T, Xiao G, Potthoff MJ, Wei W, Wan Y, Yu RT, Evans RM, Kliewer SA, Mangelsdorf DJ (2012) The starvation hormone, fibroblast growth factor-21, extends lifespan in mice. Elife 1:e00065

115. Mäkelä J, Tselykh TV, Maiorana F, Eriksson O, Do HT, Mudò G, Korhonen LT, Belluardo N, Lindholm D (2014) Fibroblast growth factor-21 enhances mitochondrial functions and increases the activity of PGC-1 $\alpha$ in human dopaminergic neurons via Sirtuin-1. Springerplus 3:2. doi:10.1186/2193-1801-3-2

116. Miyata A, Arimura A, Dahl RR, Minamino N, Uehara A, Jiang L, Culler MD, Coy DH (1989) Isolation of a novel 38 residuehypothalamic polypeptide which stimulates adenylate cyclase in pituitary cells. Biochem Biophys Res Commun 164:567-574

117. Arimura A, Somogyvari-Vigh A, Weill C, Fiore RC, Tatsuno I, Bay V, Brenneman DE (1994) PACAP functions as a neurotrophic factor. Ann N Y Acad Sci 739:228-243

118. Vaudry D, Falluel-Morel A, Bourgault S, Basille M, Burel D, Wurtz O, Fournier A, Chow BK, Hashimoto H, Galas L, Vaudry H (2009) Pituitary adenylate cyclase-activating polypeptide and its receptors: 20 years after the discovery. Pharmacol Rev 61:283-357

119. Reglodi D, Kiss P, Lubics A, Tamas A (2011) Review on the protective effects of PACAP in models of neurodegenerative diseases in vitro and in vivo. Curr Pharm Des 17:962-972

120. Spengler D, Waeber C, Pantaloni C, Holsboer F, Bockaert J, Seeburg PH, Journot L (1993) Differential signal transduction by five splice variants of the PACAP receptor. Nature 365:170-175

121. Wang G, PanJ TanYY, SunXK ZhangYF, ZhouHY RenRJ, WangXJ Chen SD (2008) Neuroprotective effects of PACAP27 in mice model of Parkinson's disease involved in the modulation of K(ATP) subunits and D2 receptors in the striatum. Neuropeptides 42:267-276

122. Lee EH, Seo SR (2014) Neuroprotective roles of pituitary adenylate cyclase-activating polypeptide in neurodegenerative diseases. BMB Rep 47:369-375

123. Lee FS, Rajagopal R, Kim AH, Chang PC, Chao MV (2002) Activation of Trk neurotrophin receptor signaling by pituitary adenylate cyclase-activating polypeptides. J Biol Chem 277:9096-9102

124. Takei N, Skoglosa Y, Lindholm D (1998) Neurotrophic and neuroprotective effects of pituitary adenylate cyclase-activating polypeptide (PACAP) on mesencephalic dopaminergic neurons. J Neurosci Res 54:698-706

125. Chung CY, Seo H, Sonntag KC, Brooks A, Lin L, Isacson O (2005) Cell type-specific gene expression of midbrain dopaminergic neurons reveals molecules involved in their vulnerability and protection. Hum Mol Genet 14:1709-1725

126. Reglodi D, Kiss P, Szabadfi K, Atlasz T, Gabriel R, Horvath G, SzakalyP Sandor B, Lubics A, Laszlo E, Farkas J, Matkovits A, Brubel R, Hashimoto H, Ferencz A, Vincze A, Helyes Z, Welke L, Lakatos A, Tamas A (2012) PACAP is an endogenous protective factor-insights from PACAP-deficient mice. J Mol Neurosci 48:482-492

127. Watson MB, Nobuta H, Abad C, Lee SK, Bala N, Zhu C, Richter F, Chesselet MF, Waschek JA (2013) PACAP deficiency sensitizes nigrostriatal dopaminergic neurons to paraquat-induced damage and modulates central and peripheral inflammatory activation in mice. Neuroscience 240:277-286

128. Delgado M, Leceta J, Ganea D (2003) Vasoactive intestinal peptide and pituitary adenylate cyclase-activating polypeptide inhibit the production of inflammatory mediators by activated microglia. J Leukoc Biol 73:155-164

129. Mäkelä J, Koivuniemi R, Korhonen L, Lindholm D (2010) Interferon-gamma produced by microglia and the neuropeptide PACAP have opposite effects on the viability of neural progenitor cells. PLoS One 5:e11091

130. Banks WA, Kastin AJ, Komaki G, Arimura A (1993) Passage of pituitary adenylate cyclase activating polypeptide1-27 and pituitary adenylate cyclase activating polypeptide1-38 across the blood-brain barrier. J Pharmacol Exp Ther 267:690-696

131. Dogrukol-Ak D, Tore F, Tuncel N (2004) Passage of VIP/ PACAP/secretin family across the blood-brain barrier: therapeutic effects. Curr Pharm Des 10:1325-1340 